\title{
RECENZJE
}

\author{
ALEKSANDER NALASKOWSKI \\ Wydział Nauk Pedagogicznych UMK \\ ORCID ID: https://orcid.org/oooo-ooo2-7739-5181
}

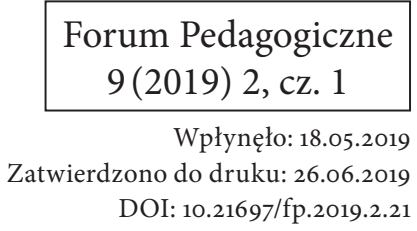

\section{Teologia pedagogiczna Heleny Słotwińskiej}

[H. Słotwińska. (2019). Wychowanie chrześcijańskie szansa integralnego rozwoju człowieka. Studium z pedagogiki religii. Kraków: Oficyna Wydawnicza „Impuls”, $626 \mathrm{s.}]$

Recenzowana książka jest źródłowo i naukowo imponująca, ale też inspirująca do dyskusji, o czym będzie mowa w dalszej części recenzji. Na początku muszę jednak wspomnieć, że drażniący jest dla mnie sposób sformułowania tytułu. Notabene ta stylistyka powtarza się w innych publikacjach Autorki i jest mocno upowszechniona w kręgach teologicznych. Być może jest to tam uzasadnione, ale na gruncie pedagogiki mniej. To stylistyka sloganowo-hasłowa. Nadająca się bardziej na transparent niż na okładkę książki naukowej. De facto taki tytuł nie stawia problemu, gdyż nie daje się zinterpretować jako pytanie. Zawarto w nim tezę, że wychowanie jest szansą integralnego rozwoju i już. Zręczniejszy byłby np. taki tytuł: Wychowanie chrześcijańskie jako szansa na integralny rozwój człowieka, czyli wychowanie chrześcijańskie widziane jako szansa na integralny rozwój, ale niekoniecznie i nie zawsze. Zatem byłoby to $w$ istocie pytanie o tę szansę, a nie orzekanie, że właśnie i bez wątpienia wychowanie chrześcijańskie ją daje. Gdyby to był tytuł podsumowania rozważań - pełna zgoda, ale jako zapowiedź tego, co ma być rezultatem dociekań, jest ich rozstrzygnięciem a priori. Tytuł nie jest tu zaproszeniem do naukowej dyskusji, ale perswazją, że coś takie właśnie jest i kropka.

Monografia została napisana przez osobę, która mimo ogromnego doświadczenia naukowego, bezwzględnie imponującego dorobku w zakresie teologii (w tej dziedzinie ma tytuł profesora), najszerzej pojętej humanistyki, a w tym filozofii, nie została zmanierowana przez nadaktywność w konferencjach pedagogicznych, nie została skażona, charakterystycznym już niestety u niektórych pedagogów ogólnych i teoretyków wychowania żargonem czy pisarską i polityczną poprawnością. Zapewne dlatego tchnie ona świeżością i odwagą naukową. Mimo obszerności i drobiazgowości czyta się ją jednym tchem, ponieważ naprawdę jest w swojej pedagogicznej odmienności ożywcza. Pod tym względem przypomina najlepsze prace Kazimierza Twardowskiego, wielkiego twórcy Szkoły Lwowsko-Warszawskiej. Jest 
bowiem przy tym precyzyjna. Jestem zdania, że powinna stać się ważnym głosem w dyskusjach nad istotą pedagogiki ogólnej.

Można mieć żal do Autorki, że zbyt rzadko przywołuje klasyków pedagogiki i kanoniczne rozprawy z tego zakresu. Ale nie jest to wszak praca dla laików, dla nowicjuszy w naszym fachu, dla osób, które tejże klasyki nie znają, którym trzeba tłumaczyć, kim byli: Sośnicki, Hessen, Nawroczyński, Mysłakowski czy Kotłowski albo Kamiński. Poza tym już teraz, bez omawiania tych zagadnień, rozprawa mocno straszy swoją objętością (prawie 700 stron!).

Niemal regułą stało się w nauce, że aplikowanie doświadczeń i wiedzy z jednej dyscypliny do innej, przy zachowaniu stosownych reżimów, owocuje efektem nowości, a niekiedy odkrywczości. Tak jest i w tym przypadku. Dostajemy rozprawę rzucającą światło na kwestie dla pedagogiki ogólnej najważniejsze, z zupełnie nieoczekiwanej perspektywy, nieuwzględnianej z powodu zaniedbania.

Jest to książka będąca solidnym i twórczym wykładem o istocie wychowania chrześcijańskiego, a właściwie o jego podstawach tkwiących w Objawieniu. Tutaj zastrzeżenie: czy naprawdę chodzi tu o całe wychowanie chrześcijańskie, a więc o ewangelików, ortodoksów, koptów, amiszów, zielonoświątkowców, a tylko przy okazji katolików rzymskich, czy może po prostu o podstawy wychowania katolickiego? Czy na gruncie rozważań pedagogicznych nie należałoby jednak tego uściślić, ujednoznacznić? Mam wrażenie, że tak. Wszak Autorka w żadnym fragmencie tekstu nie powołuje się ani na prawosławnego Paula Evdokimova, ani na protestanta Friedricha-Wilhelma Marquardt'a. Należy pisać i mówić wprost, że idzie o wychowanie katolickie, pedagogikę katolicką. Zachowujemy się tak, jakbyśmy tę katolickość ukrywali, jakbyśmy się jej wstydzili. Niepotrzebnie.

Swoistość tej monografii polega również na prowokowaniu do dyskusji o zakresie i znaczeniu pojęć. Podam jeden przykład: na stronie 273 i dalej znajdujemy rozważania i próby definiowania pojęć struktura, styl i model. To dobre prawo autora dokonywać wyboru niezbędnych instrumentów eksplikacyjnych, ale takim samym jest czytelnicze prawo do dyskusji nad takim czy innym wyborem. Otóż wydaje mi się, że struktura jest układem wertykalnym „od-do”. A zatem należy do pojęć konstrukcyjnych, ideowo i emocjonalnie neutralnych. Pod tym względem przypomina wzór matematyczny, albo lepiej - logiczny. Model zaś zawiera w sobie element pożądania, perswazyjności, a niekiedy dyktatu. Chyba jest tak, że każdy model jest pewną strukturą, ale nie każda struktura jest modelem. Nadto struktura może istnieć zarówno w świecie natury (wówczas ją odkrywamy), jak i w świecie kultury (wówczas ją tworzymy). Model zaś to wytwór czysto kulturowy, nieobecny w świecie natury. To efekt decyzji, a więc procesów normatywnych, o tym, co w sobie zawiera, a co pomija. Struktura takich procedur nie przewiduje. Orzeka bowiem o tym, co jest, podczas gdy model mówi o tym, jak być powinno, co jest potrzebne, a co zbędne (Nalaskowski 2018). Łączenie czy porównywanie tych dwóch pojęć wydaje się być pomieszaniem znaczeń. Tak jak w sporze o to, czy kwiat pachnie, czy jest wiosna. Styl natomiast wydaje się być tutaj (w odniesieniu 
do wychowania) sposobem dochodzenia do realizacji cech modelowych. W tym fragmencie opiniowanej monografii brakuje mi omówienia pojęcia systemu, a więc układu pośredniego między strukturą a modelem. System bowiem może występować zarówno w sferze natury, jak i kultury. Stanowi go bowiem zhierarchizowana struktura. Jest strukturą wertykalną, ułożoną na osi „nad-pod”. Hierarchia może wynikać z praw natury, albo z pryncypiów kultury (np. moralnych). Całej monografii nie zaszkodziłaby jeszcze większa precyzja terminologiczna. To bardzo ważny element metodologii pedagogicznej.

Druga uwaga dotyczy specyficzności wychowania chrześcijańskiego w ujęciu Autorki (s. 280 i nast.). Wymienione elementy są, jak się zdaje, dość uniwersalnie i nie stanowią o specyfice wychowania chrześcijańskiego. Stanowią raczej to, co je łączy z najszerzej pojętym wychowaniem, bez żadnego przymiotnika. To tylko zmienne, których zawartość dopiero będzie decydować o charakterze procesu i fenomenu takiego czy innego wychowania. Nadto trudno na podstawie tej listy wywnioskować, czy mowa jest o wychowaniu jako procesie, czy efekcie.

Podobnych uwag miałbym więcej, ale jak można bez trudu zauważyć, byłyby one tyleż przyczynkarskie, co dyskusyjne. Mam też pełną świadomość, że pewne uproszczenia czy potknięcia mogą być ceną za świeżość i inność pracy. Mogą być efektem wchodzenia na grunt subiektywnie nieznany, co w dużej mierze warunkuje/może warunkować uruchamianie myślenia uwolnionego od zastanych schematów, utartych sposobów formułowania myśli i ujmowania rozpoznanego problemów naukowych. Tak jest w przypadku tej monografii. Jak wcześniej oceniłem - to naprawdę ożywcze i nowatorskie spojrzenie, potrzebne naszej pedagogice ogólnej jak nurkowi tlen. Niewiele jest tak dobrze napisanych monografii przedstawiających pedagogikę wywiedzioną z Objawienia i nauki Jezusa Chrystusa. Helena Słotwińska nie jest naukowym kameleonem. Warsztat teologiczny aplikuje do pedagogiki. Robi to twórczo i ze znakomitymi efektami.

Książka Heleny Słotwińskiej to obszerne i wyczerpujące studium z pedagogiki chrześcijańskiej, a precyzyjniej - katolickiej. Stanowi niezwykle ważny pomost, groblę pomiędzy np. pedagogią Jana Pawła II a pedagogiką klasyczną, rzec by tu można, akademicką. To w końcu efekt nieprawdopodobnej pracy, nomen omen benedyktyńskiej, a nade wszystko udana próba agregacji kompetencji teologicznych i pedagogicznych Autorki. Jeśli tylko przeczyta się kilkanaście, kilkadziesiąt stron monografii, to wątpliwości co do jej „pedagogiczności” mijają, stają się nieadekwatne. To także praca na czasie. Ukazała się w momencie rozmydlania z jednej strony i nadmiernego obmodlania z drugiej chrześcijańskiej myśli pedagogicznej. Nie jest to bynajmniej tylko książka dla wierzących. Kwestia wiary nie jest tu rozstrzygająca. Jest to bowiem praca charakteryzująca pewne pedagogiczne podejście, wykładająca jego istotę, sposób widzenia świata, rolę wychowania w tak odbieranym świecie. Mam wrażenie, że o ile dla badaczy katolickich światopogląd niekatolicki nie jest poznawczo obcy, czego dowodem może być książka Karola Wojtyły Mężczyzna i kobieta stworzył ich, tyle na odwrót już jest znacznie gorzej. 
Moim zdaniem, znajomość reguł pedagogicznych wywiedzionych z wiary katolickiej (ale też z innych religii) jest koniecznością naukową, bez względu na osobisty do nich stosunek. Kościoła, jego urzędu nauczycielskiego i wpływu nie da się w profesjonalnej pedagogice akademickiej zignorować ani urzędowo zadekretować jego nieistnienia. I taką właśnie rolę poznawczą pełni opiniowana rozprawa główna. To jej ogromny atut.

Można szukać słabych stron monografii. Można, poprzez wskazywanie na brak związków z pedagogiką, wytykać Autorce niewielką liczbę publikacji w czasopismach stricte pedagogicznych, niewielki jej udział w naszych branżowych konferencjach. Czy unieważnia to jednak pedagogiczną zawartość jej ostatniej monografii? Czy fakt, że czegoś nie znamy (z różnych przyczyn i także nie z własnej winy) oznacza, że to nie istnieje? Po prostu ta monografia jest pedagogiczna, gdyż jest w niej pedagogika. I tyle.

I ostatni już walor tej publikacji. Uwidacznia ona, jak sztuczny jest obecny podział dziedzin na humanistyczne, społeczne i teologiczne. Autorka próbuje je znów po tym „rozbiciu dzielnicowym” scalić w jeden organizm naukowy.

\section{Bibliografia}

A. Nalaskowski (2018). O względności czasu w modelach rozwoju dziecka. Wykład akademicki. Kraków: Oficyna Wydawnicza „Impuls”. 